\section{Federal Emergency Management Agency}

(FEMA). Access: http://www.fema.gov.

At first glance, the website for FEMA is not an obvious choice for academic research. The homepage features current news and events, with highlighted quick tips and video content from the creative "Ready" kids site. Digging a bit deeper via menu options or the site's search engine, researchers will find documentation and data relating to national disaster planning, preparedness, and recovery. The site offers multiple options for navigation, including a Bing-driven basic and advanced search and multiple layers of menus.

On one level, FEMA's website provides user-friendly access to home and business owners who wish to be informed and prepared. With links to applications for assistance, tips for building a preparedness kit, and referrals to local assistance centers and agencies, the site is a one-stop practical resource. FEMA's variety of social media tools provides multiple options for staying abreast of news releases from the agency.

Anyone looking at data relating to declared disasters will find useful tools via the site. The interactive map on the homepage is one gateway to data, with its links to stateby-state chronological listings of federally declared disasters. Each link points to a page with updates, geographical information, and data on federal assistance. "OpenFEMA" offers data feeds on public assistance-funded projects as well as hazard mitigation grants.

FEMA provides free downloads of its Hazus software. This program estimates loss and impact of disasters using GIS. User guides and technical assistance are provided. Flood mapping is available via the Risk Mapping, Assessment and Planning program (Risk

Joni R. Roberts is associate university librarian for public services and collection development at Willamette University, e-mail: jroberts@willamette.edu, and Carol A. Drost is associate university librarian for technical services at Willamette University, e-mail: cdrost@ willamette.edu
MAP). The site also provides levee mapping and linking to the National Levee Database of the U.S. Army Corps of Engineers and National Seismic Hazard Maps from the U.S. Geological Survey.

The FEMA site is a good choice for national policy research. The "National Preparedness Resource Library" provides access to current documentation from the Department of Homeland Security, including the National Planning Frameworks, the annually updated "National Preparedness Report," and publications of the National Incident Management System.

For research relating to disaster planning, preparedness, and response, FEMA's website is a good recommendation for disaster mapping and government reports.-Ann Flower, Monterey Institute of International Studies, aflower@miis.edu

The National Constitution Center (NCC). $A C$ cess: http://www.fema.gov.

NCC offers an attractive interface designed to engage Americans and others with the text and evolving interpretation of the United States Constitution. NCC aims to promulgate general and nonpartisan information about civic education.

Beyond its mission of enhancing and extending the experience of visitors to its physical facility in Philadelphia, the NCC website presents educational materials to broader audiences-particularly K-12 students and educators. One module includes lesson plans for general civic topics such as the legacy of September 11 and the Fourth of July. Also on the site is a more specialized series of videos and educational webinars about constitutional law, which may satisfy some Continuing Legal Education requirements. Another useful feature on the site is the Constitution Daily blog, which includes podcasts, interviews, and articles of topical interest.

The NCC site does not function as a repository of digitized documents and other 
unique collections. It does, however, provide a convenient gathering of key constitutional texts with links to added commentary from entities such as the Leonore Annenberg Institute for Civics. The usefulness of these offerings would be enhanced by more explicit citation instructions and annotated bibliographies. Web portals with an emphasis on U.S. historical documents, such as the National Archives and the Gilder Lehrman Collection, offer richer documentary content in tandem with educational modules at various levels.

NCC's selection of recorded speeches and presentations (some of which are also available on NCC's social media platforms) are well produced and cover many topical areas related to American law and public affairs. These substantive videos, based on somewhat vague and abstract connections to the Constitution, may struggle to stand out among the wide array of content available about such topics elsewhere.

In sum, the NCC website is a usable and conscientious outreach effort that delivers general content about the U.S. Constitution and its interpretation. This relatively new organization (started in 2003) is working to expand its virtual programming while maintaining its core focus, and may merit further consideration in the future. Postsecondary students involved in teacher training programs and service-learning initiatives may find interesting tools here, but others should consider pursuing more targeted tools and approaches._Joshua Lupkin, Tulane University, jlupkin@tulane.edu

The Willa Cather Archive. Access: http:// cather.unl.edu/.

The Willa Cather Archive is an ambitious and wide-ranging digital archive that aims to provide access to a vast array of materials relating to Cather studies, including works both by and about Cather. The Willa Cather Archive has solid scholarly credentials: it is peer reviewed by NINES (Networked Infrastructure for Nineteenth-Century Electronic Scholarship) and overseen by Associate Professor of Digital Projects Andrew Jewell, alongside prominent Cather scholars Janis Stout and Melissa Homestead.

The Willa Cather Archive is produced by a partnership between the Cather Project, Archives and Special Collections at the University of Nebraska-Lincoln (UNL) Libraries, the University of Nebraska Press, and the UNL Center for Digital Research in the Humanities.

Because of this collaboration between scholars, publishers, librarians, and digital humanists, the archive brings together multiple threads in Cather studies by reproducing images of Cather, texts (many of which have never been collected before), scholarly editions, and scholarly articles. Of particular interest are the open access UNL Press scholarly editions of five of Cather's novels, including My Ántonia and O Pioneers!

The site is divided by type of material: "Writings," "Letters," "Life," "Gallery" (which contains a dizzying array of photographs of Cather from babyhood on), "Multimedia" (not least of which is a rare video of Cather in action), "Scholarship," "Text Analysis," and "Community."

The letters section includes a calendar of Cather's letters; the complete letters will be added beginning in 2018 when they enter the public domain. The writings section is particularly rich, including reproductions of first editions of Cather's novels, as well as her short stories and journalism. Scans of the texts in the original periodical publications include the accompanying illustrations.

Visitors to the site can search four separate sets of materials: digital texts, images, the calendar of letters, and material in NINES. The "Geographic Chronology" section draws on location references in Cather's letters to map Cather's travels throughout her lifetime.

The Willa Cather Archive offers rich resources for beginning and advanced Cather scholars, and it is also a model of the possibilities for collaboration between librarians, scholars, presses, and digital humanists to create useful, freely available materials for researchers.-Sigrid Anderson Cordell, University of Michigan, scordell@ umich.edu $\mathrm{n}$ 